\title{
Comparative Susceptibility of Four Olive Cultivars For Infestation by The Olive Psyllid, Euphyllura straminae Longnova in Burg El-Arab Area, Alexandria, Egypt
}

\author{
Hassan A. Mesbah ${ }^{1}$, Khadiga S. Moursi ${ }^{2}$, Magda B. El-Kady ${ }^{1}$, Saad H.D. Masry ${ }^{3}$, Nadia M. Hassona ${ }^{1}$ and \\ Yasmine A.T. Abd El-Motelb ${ }^{3}$
}

\begin{abstract}
The present study was carried out on four olive cultivars to determine the susceptibility of each cultivar for infestation by the cotton olive psyllid, Euphyllura straminae during three successive growing seasons (20142016) in the Experimental Farm of City of Scientific Research and Technological Applications), Burg El-Arab area. the obtained data revealed that tophahy cultivar is the most susceptible one to infestation with $E$. straminae, followed by the picual cultivar, while shemlali and kalamata were less susceptible to infestation with $E$. straminae. By estimating the effect of cardinal directions of the grown olive trees yard on average rate of infestation for each of four inspected cultivars; it was revealed that the highest infestation was detected for the grown tophahy cultivar in the Southern direction of the yard, followed by the grown picual trees in the Northern direction; then shemlali trees in the Southern direction; and the growing kalamata trees at the Eastern side of the plantation yard.
\end{abstract}

Key words: Olive (Olea eropaea L.), Euphyllura straminae, susceptibility, cardinal directions.

\section{INTRODUCTION}

Olive (Olea eropaea L.) is one of the oldest domesticated fruits in the world where it was has been grown for many centuries and is still among the most important trees. These trees number are about 800 million and occupy a surface area of approximately 10 million hectares. The Mediterranean basin produce about 1.6 million metric tons per annum of olive oil, in addition to 750000 metric tons of table olive-about 9\% of the area production of olive (Alfonso and Owen, 2002). In Egypt, olive cultivation goes back thousands of years specially at Borg El-Arab then spread successfully along the coast. Its cultivated area has been expanded largely in the last decade, particularly in new reclaimed arid lands (Western side of Nil). Its area reached 49000 hectares in 2010 (productivity $=6327 \mathrm{~kg}$ / Hectare). Olive trees is subjected to attack by many

DOI: 10.21608/asejaiqjsae.2019.52576

${ }^{1}$ Department of plant protection, Faculty of Agriculture Saba Basha,

Alexandria university, Egypt

${ }^{2}$ Depatment of plant protection, Agricultural researches center

${ }^{3}$ Department of plant protection and molecular diagnosis,

Arid lands cultivation researches institute, City of scientific research

and technological applications.

Received September 1, 2019, Accepted September 30, 2019 insect pests that affect yield quality and quantity among the most common pest species surveyed in Egypt (Sabbour et al 2012).

The olive psyllid Euphyllura straminae was firstly collected and identified from olive trees at El-Arish and Rafah, where the trees were heavily infested during 1988. Two years later, olive trees at El-Fayoum were also heavily infested with this pest and growers suffered great losses in their olive crop (Nada, 1994), later it was appeared in Burg El-Arab area during 1997 (Moursi, 1999).

Many ecological and toxicological studies were carried out on this pest species during the period of 1986 till now (Abo-Shanab, 2000; Elwan, 2001; Abd Rabou and Ahmed, 2011 and Abdel-Fattah et al, 2015).

Therefore, this article aimed to estimate the infestation rate by E. straminae on four cultivars and determine the susceptibility of these cultivars for infestation, besides the effect of cardinal direction of growing olive trees in the plantation yard on the infestation percentage.

\section{MATERIALS AND METHODS}

The study was carried out to determine the susceptibility of four olive cultivars to infestation by olive psyllid Euphyllura straminae (Fig.1), during three growing seasons (April- November) of 2014, 2015 and 2016, the inspected olive cultivars were kalamata, tophahy, picual and shemlali.

The study took place at the experimental farm of the City of Scientific Research and Technological Applications (SRTA-City), New Burg El-Arab city, Alexandria, Egypt.

Five trees in the same age of each cultivar, similar in size, shape and height and not exposed to any chemical control during the period of study were selected for this study. 
The samples were collected every two weeks from each cardinal direction of every selected tree, inspection and sampling was run at the upper, middle and lower levels. A total of 12 samples were collected from each individual replicated tree of each cultivar. Moreover, these samples contained (twigs, leaves, flowers, fruits and branches).

Thereafter, all samples were transferred directly to the laboratory in cloth bags for classifying and counted by a stereoscopic binocular microscope.

In an effort to estimate the distribution of population densities and rate of infestation of the detected insect, the obtained data were statistically analyzed according to (Snedecor,1970).

\section{RESULTS}

Data presented in (table 1) indicate the monthly variations in calculated infestation rates with Euphyllura sraminae on four olive cultivars at Burg ElArab during the subsequent seasons of 2014-2016. In season of 2014, the highest infestation rate was recorded in July $(35.3 \%, 41.7 \%, 43.4 \% 42.6 \%)$ for shemlaly, picual, tophahy and kalamata respectively. Moreover, in May 2015 it was $(30.3 \%, 51.6 \%$ and $43.5 \%$ ) for picual, tophahy and kalamata respectively, but in shemlaly was $28.8 \%$ in June. While, in the season of 2016 , it was $31.3 \%$ in May for tophahy cultivar and in June in shemlaly with $28.8 \%$, picual with $26.9 \%$ and kalamata with $25 \%$. The infestation rate was decreased in October and November.

As shown in Fig. (2) the effect of cardinal directions on the distribution of E. straminae, in shemlali cultivar the highest infestation rate recorded in the Southern direction with average (35.33 nymphs and adults), followed by picual cultivar in the Northern direction with average (42.33 nymphs and adults), then tophahy cultivar with average (73 nymphs and adults ) in the Southern direction. In kalamata cultivar the Eastern direction was the highest average (28.33 nymphs and adults).

The seasonal variation in the level of leaves infestation of four olive cultivar by E. straminae is illustrated in (Fig. 3). Differences were detected concerning the susceptibility of leaves of olive cultivars to E. straminae infestation. The highest grand total of E. straminae infestation by nymphs and adults was observed on tophahy cultivar (727, individuals with a ratio of $38.28 \%$ ) of the total grand count, followed by picual (462, individuals) with $(24.3 \%)$, then shemlali (410, individuals with a ratio of $21.59 \%$ ); the least was kalamata (300,individuals represented $15.79 \%$ ). The infestation rate $(\%)$ reached the maximum during the season of 2016 for all cultivars under study.

\section{DISCUSSION}

In accordance with our above cited results, the obtained results by Abo-Shanab (2000) revealed that the olive psyllid E. straminae appeared at the winter of 1999 (late February and early March) where it was $17 \%$, then increased gradually till it reached $23 \%, 40 \%$ and $48 \%$ during April, May and June, respectively. During July the infestation average percentage decreased to be $45 \%$, then continued decreasing sharply to become $4 \%$ during August and reached the minimum infestation average percentage $1 \%$ by the beginning of winter. He also showed that the infestation rate was higher in the irrigation farm than in the farm under rainfed on shemlali cultivar. He also, added that the day light was one of the most important weather factors that affected and correlated greatly with the activity of $E$. straminae in northern western coast of Egypt.

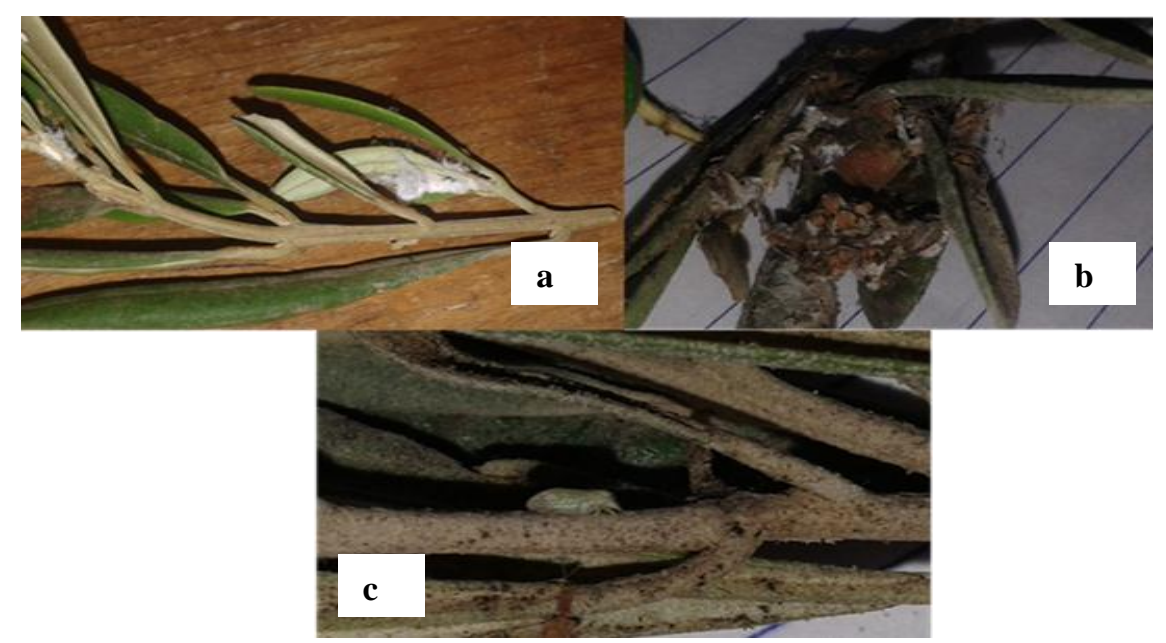

Fig. 1. The olive psyllid (Euphyllura straminae) a: Nymph; b: Symptoms and c: Adult 
Table 1. Monthly variation in the infestation rate of four-olive cultivars by Euphyllura straminae during April 2014 up to November 2016 at Burg ElArab area.

\begin{tabular}{|c|c|c|c|c|c|c|c|c|c|c|c|c|c|c|c|c|c|c|c|c|c|c|c|c|}
\hline \multirow{3}{*}{$\begin{array}{c}\text { variety } \\
\text { Date of inspect }\end{array}$} & \multicolumn{6}{|c|}{ shemlali } & \multicolumn{6}{|c|}{ picual } & \multicolumn{6}{|c|}{ tophahy } & \multicolumn{6}{|c|}{ kalamata } \\
\hline & \multicolumn{2}{|c|}{2014} & \multicolumn{2}{|c|}{2015} & \multicolumn{2}{|c|}{2016} & \multicolumn{2}{|c|}{2014} & \multicolumn{2}{|c|}{2015} & \multicolumn{2}{|c|}{2016} & \multicolumn{2}{|c|}{2014} & \multicolumn{2}{|c|}{2015} & \multicolumn{2}{|c|}{2016} & \multicolumn{2}{|c|}{2014} & \multicolumn{2}{|c|}{2015} & \multicolumn{2}{|c|}{2016} \\
\hline & No. & $\%$ & No. & $\%$ & No. & $\%$ & No. & $\%$ & No. & $\%$ & No. & $\%$ & No. & $\%$ & No. & $\%$ & No. & $\%$ & No. & $\%$ & No. & $\%$ & No. & $\%$ \\
\hline April & 0 & 0 & 3 & 5.77 & 22 & 8.33 & 0 & 0 & 11 & 16.7 & 57 & 20.1 & 0 & 0 & 26 & 16.4 & 105 & 26.1 & 0 & 0 & 5 & 7.25 & 31 & 19.9 \\
\hline May & 4 & 55.8 & 10 & 19.2 & 54 & 20.5 & 5 & 4.85 & 20 & 30.3 & 72 & 25.4 & 30 & 18.9 & 82 & 51.6 & 126 & 31.3 & 8 & 11.8 & 30 & 43.5 & 34 & 21.8 \\
\hline June & 16 & 23.5 & 15 & 28.8 & 76 & 28.8 & 19 & 18.4 & 13 & 19.7 & 76 & 26.9 & 31 & 19.5 & 22 & 13.8 & 83 & 20.6 & 6 & 8.82 & 9 & 13 & 39 & 25 \\
\hline July & 24 & 35.3 & 5 & 9.62 & 26 & 9.85 & 43 & 41.7 & 4 & 6.06 & 31 & 11 & 69 & 43.4 & 8 & 5.03 & 29 & 7.21 & 29 & 42.6 & 9 & 13 & 10 & 6.41 \\
\hline August & 6 & 8.82 & 7 & 13.5 & 33 & 12.5 & 11 & 10.7 & 5 & 7.58 & 18 & 6.36 & 24 & 15.1 & 5 & 3.14 & 17 & 4.23 & 16 & 23.5 & 3 & 4.35 & 22 & 14.1 \\
\hline September & 7 & 10.3 & 1 & 1.92 & 28 & 10.6 & 16 & 15.5 & 5 & 7.58 & 18 & 6.36 & 3 & 1.89 & 6 & 3.77 & 17 & 4.23 & 3 & 4.41 & 3 & 4.35 & 11 & 7.05 \\
\hline October & 4 & 5.88 & 5 & 9.62 & 19 & 7.2 & 4 & 3.88 & 6 & 9.09 & 7 & 2.47 & 1 & 0.63 & 8 & 5.03 & 14 & 3.48 & 3 & 4.41 & 8 & 11.6 & 4 & 2.56 \\
\hline November & 7 & 10.3 & 6 & 11.5 & 6 & 2.27 & 5 & 4.85 & 2 & 3.03 & 4 & 1.41 & 1 & 0.63 & 2 & 1.26 & 11 & 2.74 & 3 & 4.41 & 2 & 2.9 & 6 & 3.85 \\
\hline Total & 68 & & 52 & & 264 & & 103 & & 66 & & 283 & & 159 & & 159 & & 402 & & 68 & & 69 & & 156 & \\
\hline Garnd total & \multicolumn{6}{|c|}{384} & \multicolumn{6}{|c|}{452} & \multicolumn{6}{|c|}{720} & \multicolumn{6}{|c|}{293} \\
\hline $\begin{array}{l}\text { \%total of grand } \\
\text { total }\end{array}$ & \multicolumn{2}{|c|}{17.7} & \multicolumn{2}{|c|}{13.54} & \multicolumn{2}{|c|}{68.75} & \multicolumn{2}{|c|}{22.78} & \multicolumn{2}{|c|}{14.6} & \multicolumn{2}{|c|}{62.61} & \multicolumn{2}{|c|}{22.08} & \multicolumn{2}{|c|}{22.08} & & & & & & & & \\
\hline Avarge/3seasons & & & & & & & & & & & & & & & & & & & & & & & & \\
\hline
\end{tabular}




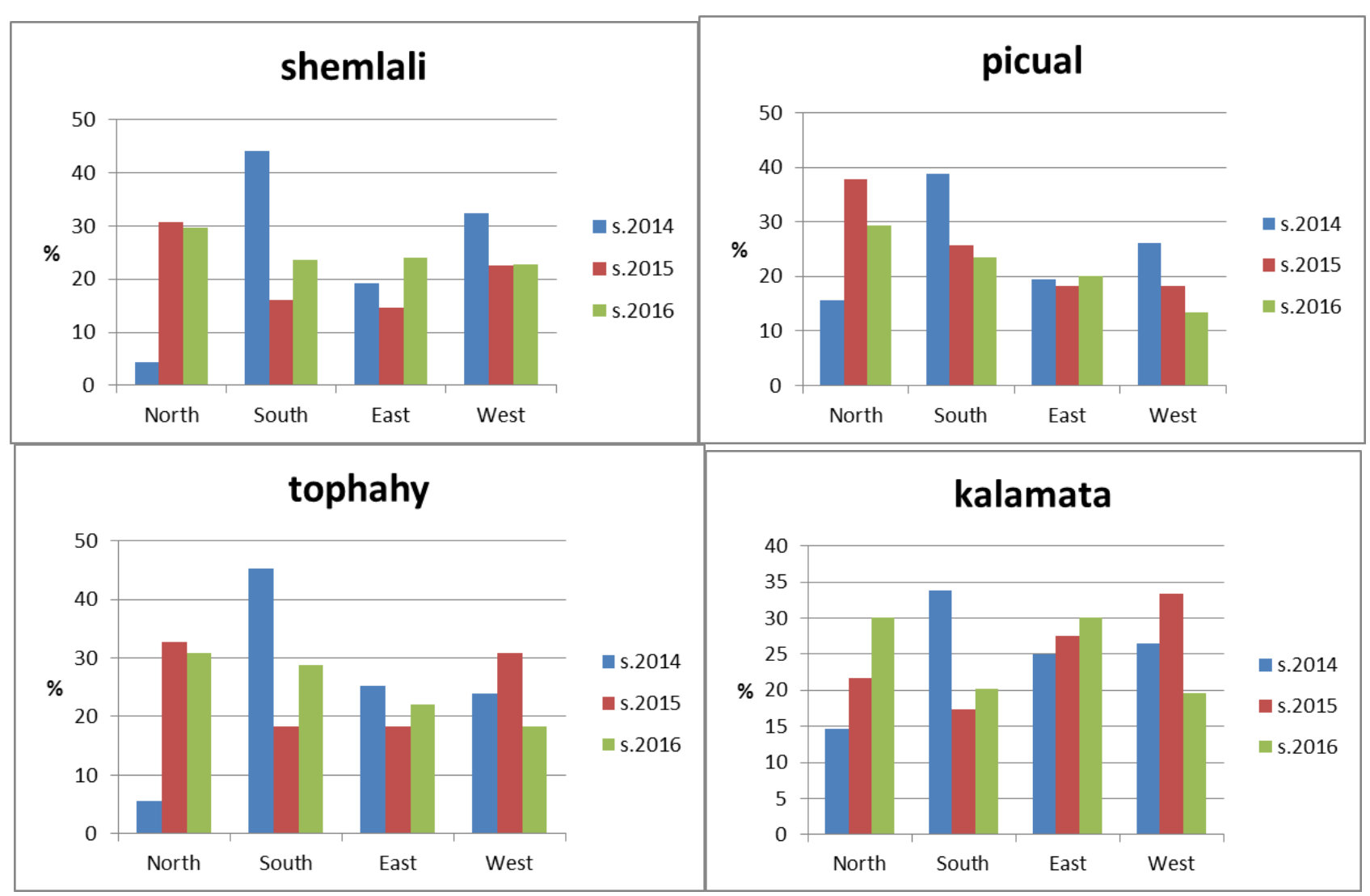

Fig. 2. Effect of cardinal directions on the estimated rates of infested leaves by Euphyllura straminae on the inspected varieties of growing olive trees at Brog El-Arab, Alex., gov., throughout the following seasons of 2014 up to 2016. 


\section{abundancy (\%)}

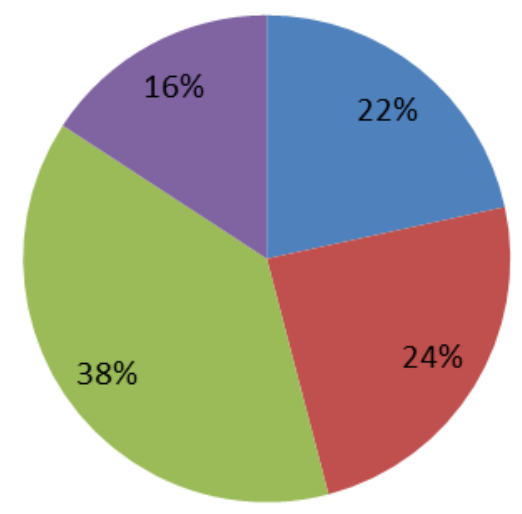

Shemlali

picual

Tophahy

Kalamata

Fig. 3. Infestation abundancy (\%) Euphyllura straminae on four olive cultivars in Burg El-Arab area, Alex. during three subsequent seasons (2014-2016).

\section{REFERENCES}

Abdel-Fattah, R., S., Beshr, H. Sahar, H. S. Hussein, A.M.Z., Lamya. and A.S. Abo-Shanab. 2015. Ecological and toxicological studies on cottony olive psylla, Euphyllura straminae Loginova (Homoptera: Aphalaridae) infesting olive trees at west north coast, Egypt. Egy. J. Palnt. Pro.Res.3(2):1-18.

Abd-Raboou, S. and N.Ahmed. 2011. Seasonal incidence of scale insects, whiteflies and psyllids (Hemiptera) of olive and their natural enemies in Egypt. Egypt. Acad. J. biolog. Sci. 4 (1): 59 -74.

Abo-shanab, A.S.H. 2000. Efficiency of biocides and insecticides on control of an Economic pest " population dynamics" and integrated pest management of psyllid, Euphyllura straminae on olive trees in burg el-Arab. Ph.D. Thesis, Fac. of Agric. Alex. University, Egypt.
Alfonso, M. B. and J. Owen. 2002. Alternative methods for controlling the olive fly Bactrocera oleae, involving semiochemicals. IOBC wprs Bulletin, 25 (Gmelin) (Diptera: Tephirtidae) in the laboratory. Plant Prot. Sci. 3: 98-102.

El-wan, E.S.A.H. 2001. Ecological studies on the olive psyllid, Euphyllura straminea Loginova (Homoptera: Psylloidea: Aphalaridae) in Al-Arish, North Sinai, Egypt. Egypt. J. Agric. Res.79(1): 161-178.

Moursi, K.S. 1999. Integrated pest management of olive, Almond and Fig in Northern Western coast of Egypt. Report $4^{\text {th }}$ (Project No.12) (Unpublished).

Nada, Samia, M.A. 1994. Olive psyllid, Euphyllura straminae Longinova, an olive pest new to Egypt (Homoptera: Psyllidae) Egypt. J. Agric. Res.72(1)129-131.

Sabbour, M.M., M.A. Abd El Rahman and Rragei, A. 2012. Pathogenicity of entomopathogenic fungi against olive insect pests under laboratory and field conditions in Egypt. Applied Sciences Research. 8(7).

Snedecor, G.W. 1970. Statistical methods. IOW state College, mes.U.S.A.537pp. 
ALEXANDRIA SCIENCE EXCHANGE JOURNAL, VOL. 40, No.3. JULY- SEPTEMBER 2019

516

الملخص العربي

مقارنة حساسية اربع اصناف للزيتون اتجاه الإصابة بحشره الزيتون القطنية في برج العرب،

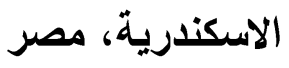

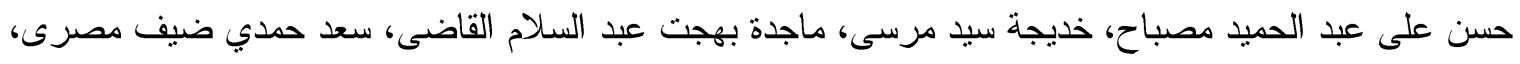
نادية محمد خميس حسونة، باسمين احمد نوفيق عبد المطلب

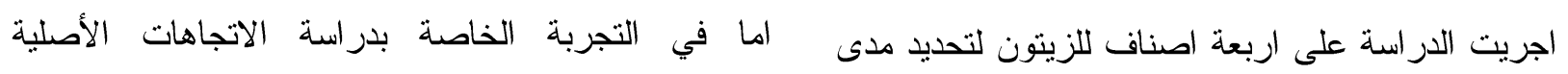

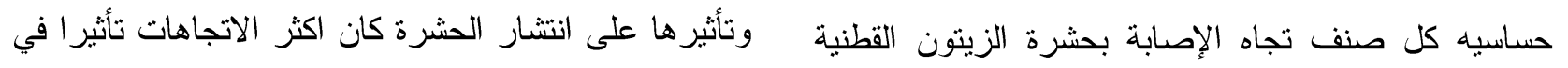

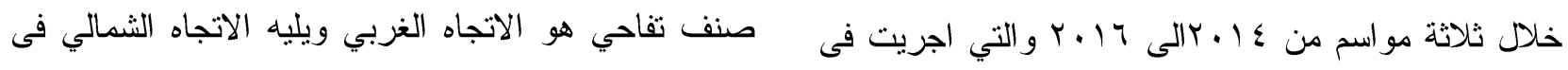

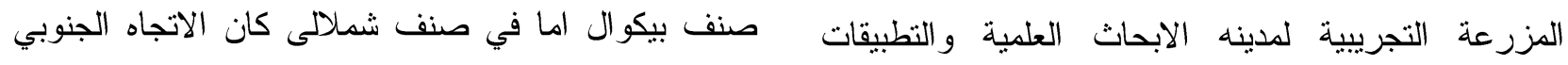

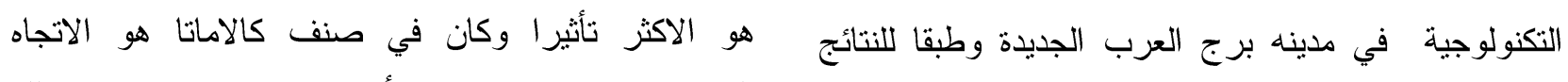

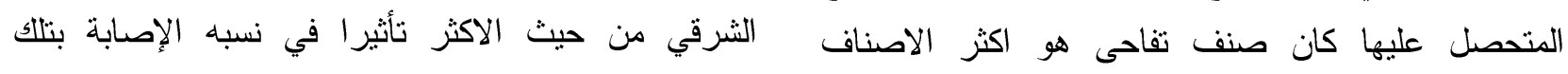

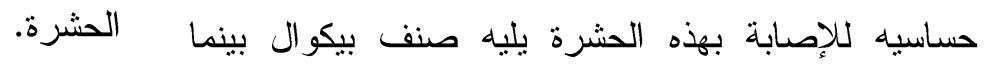

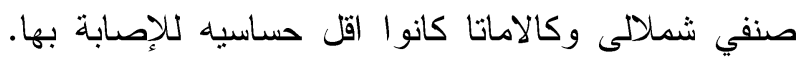

